Article

\title{
Does Ethical Behavior of Management Influence Financial Reporting Quality?
}

\author{
Chaechang $\operatorname{Im}^{1}$ and Giseok Nam ${ }^{2, *}$ (i) \\ 1 Department of Accounting, Andong National University, Andong 36729, Korea; imcee@anu.ac.kr \\ 2 College of Business, Hankuk University of Foreign Studies, Seoul 02450, Korea \\ * Correspondence: gsnam05@hufs.ac.kr
}

Received: 7 July 2019; Accepted: 1 October 2019; Published: 17 October 2019

\begin{abstract}
This paper aims to examine the relationship between managerial ethics level and financial reporting quality mainly focusing on accounting conservatism. Recently, there has been evidence to support the argument that managerial ethics level can affect reporting quality in the business world. Hence, this paper seeks to compare both fraud and non-fraud firms in terms of their ethical practice in the business. Furthermore, this study provides a more realistic perspective by making a comparison with previous studies. To test the hypotheses, we chose 243 fraud firms and compared them with the same number of non-fraud firms listed in the KOSPI and KOSDAQ from 2005 to 2012. The analysis using two groups across the time horizon reveals that the measured values of accounting conservatism do not show any meaningful difference between fraud and non-fraud firms. Additionally, fraud firms have greater absolute discretionary accruals than their counterparts. This result suggests that fraud firms are more likely to manipulate their earnings than the non-fraud firms. Also, accruals quality of fraud firms is lower than that of non-fraud firms. The significance of the paper lies in the fact that we used different criteria to judge a company's comparative ethics level.
\end{abstract}

Keywords: managerial ethics; financial reporting quality; accounting conservatism; fraud

\section{Introduction}

Firms strive to improve their value by efficiently utilizing the resources provided by interested parties, such as shareholders, debtors, and regulators. In particular, managers directly operate and manage their business activities with fiduciary responsibilities. They, in turn, provide accounting information to outsiders of the company in order to help them make appropriate financial decisions. Financial statements are very important sources for stakeholders, especially when they try to make decisions. A firm's annual report, disclosure, MD\&A (Management Discussion and Analysis) and non-financial report also provide significant information to outsiders. Therefore, a firm's financial performance as well as the quality of reporting is likely to reflect the fulfillment of the manager's fiduciary responsibilities and reporting obligation. Consequently, when a company's financial performance is determined by the ability of the manager, the reporting quality would reflect the manager's level of ethics. Such reporting quality is defined in different aspects; they can be interpreted in terms of reliability of accounting information, earning's quality, appropriate audit activity and accounting transparency. It is the quality of financial reporting that affects the company's cost of capital as well as the interested parties' decision-making [1].

Jianu et al. [2] demonstrates that sustainability positively influences the performance from the perspective of firms' marketing and reporting, they argue that a company's market positioning can be strengthened by sustainability and marketing reports. If it is true, firms' reporting could be a tool for marketing and public relations documents, and its high quality would lead to sustainable management as well as better positioning on capital markets. 
Globally, a firm's level of ethics and its ethical characteristics are being recognized as important factors for survival in the market in recent years. In the past, corporations used to focus on profit maximization; however, they were required to expand their role in order to mediate the conflict among various interested parties. Ethical practice of business has become an important issue in society with emphasis on firms' social responsibilities. Due to the development of information technology, deregulation, and the strengthening of consumers' rights, the demand for ethical practice of business as well as improving the level of consciousness have increased.

Under the circumstances, if a manager's characteristic, morality, and ethicality affect various corporate activities, we can predict that they can also affect the accounting reporting quality. More specifically, if a manager's level of ethics affects the reporting quality, which is substantial in financial decision-making for interested parties, we need to examine the relationship between the level of a manager's ethics and the quality of financial reporting. In the same context, some literatures examined this relation. Jones and Loe et al. [3,4] argue that ethics of a corporation affects general corporate activities and a high level of ethics prevents the manipulation of accounting information. The obvious example to explain this relation can be Enron's accounting scandal in 2001. Considered as the worst accounting fraud in history, Enron took advantage of the accounting flexibility and withheld relevant information regarding its low profitability and high risk, only to go through a bankruptcy process [5].

In South Korea, since the late 1990s, managerial ethics has been strongly emphasized in the realm of business because the government regarded the moral hazard and lack of transparency of financial reporting in corporations as the main cause of the financial crisis at that time. Accordingly, various researchers have attempted to examine the relation between the level of corporate ethics and the quality of accounting reports. Moon [6] examines business ethics as to how it affects the transparency of financial reporting by looking at the discretionary accruals. She suggests that firms that established a business ethics code conveyed higher accounting reporting quality than those that did not. In addition, Pae and Choi [7] provide the ECI (Ethical Commitment Index) (The Ethical Commitment Index indicates a firm's levels of ethics) and examine the relation between business ethics and accounting report quality, such as discretionary accruals, accounting conservatism, and accruals quality. The result also presents that firms with higher ECI have higher reporting quality. Overall, these results prove the reporting activity as one of the manager's activities as well as reflect on the level of their moralities and ethics.

However, the literature is limited in that they do not measure a firm's level of ethics properly and effectively. Thus, this paper attempts to solve this problem by using a sample of fraud firms and non-fraud firms. We acknowledge that fraud cases may generally reflect the level of ethics and therefore examined the relation between managerial ethics and reporting quality by comparing fraud firms with non-fraud firms. While Pae and Choi [7] developed ECI from a survey among corporate managers and Moon [6] used the adoption of an Ethics Code as the measure for business ethics, we differentiated between fraud firms and non-fraud firms in terms of reported cases of embezzlement and dereliction of duty. Therefore, we provided a more tangible and obvious proxy to test the relation between the level of ethics and the quality of financial reporting. One of the shortcomings of Pae and Choi's survey, from which they developed ECI, is that the answers might be untruthful. In the same light, as criminals not wanting to admit their crime, managers withholding negative information might not want to reveal their true sentiments [7]. It is likely that ECI has severe measurement errors in terms of the true level of ethics. Meanwhile, Moon [6] uses firms that adopted the Business Ethics Code as the measure for her ethical standard. However, Loe et al. and Stevens argue that the Business Ethics Code does not guarantee a corporation's ethics level and therefore, the Business Ethics Code is not an appropriate criterion $[4,8]$. Therefore, we use a more suitable criterion in order to evaluate the level of ethics by using a fraud firm sample in terms of embezzlement and dereliction of duty from KIND (Korean Investor's Network for Disclosure System)). Hence, we attempted to mitigate the problem of coming up with a proper measure. Finally, we examined the relation between managerial ethics level and financial reporting quality, mainly focusing on accounting conservatism. 


\section{Literature Analysis and Development of Hypothesis}

\subsection{Managerial Ethics and Fraud Firm}

Most researchers assume that managers seek their private interest rather than enhance their firm's value. However, Norreen [9] argues for a need to expand the research perspective in a more comprehensive light in terms of manager behavior. A manager's behavior affects non-economic incentives as well as economic incentives, such as conscience, religion, culture, and individual characteristic. Schwepker and Ingram, Wimbush and Sherpard, and Wimbush also argue that corporate culture is related to a manager's ethical behavior [10-12].

Corporation ethics determines the level of manager ethics; moreover, it also influences the firm's financial performance and non-financial performance. Most studies that relate a firm's ethics level with performance suggest that a corporation's ethics level and firm performance show a positive relationship [13-15]. Additionally, Epsten et al. [16] report that corporate ethical activities are favored by investors when it comes to their financial decision-making In Europe, investors consider ethicality when they trade their stocks [1,17]. Institutions such as universities, pension funds, and religious organizations hold fewer stocks in non-ethical firms [18]. Meanwhile, Moon [6] reports that firms that adopted the code of ethics have a higher ratio of operating profit to sales than firms that did not. Table 1 shows various studies which find the relationship between business ethics and corporate performance.

Table 1. Distribution of Fraud Firms by Year in Korea.

\begin{tabular}{ccccccccc}
\hline \multicolumn{7}{c}{ Panel A: Distribution of Fraud Firms by Year in Korea } \\
\hline Year & 2005 & 2006 & 2007 & 2008 & 2009 & 2010 & 2011 & 2012 \\
\hline Frequency & 23 & 16 & 37 & 64 & 38 & 20 & 23 & 22 \\
\hline \multicolumn{3}{c}{ Panel B: Distribution of Fraud Firms by Stock Market Type in Korea } \\
\hline Market & \multicolumn{5}{c}{ Frequency } \\
\hline KOSPI & 56 \\
\hline KOSDAQ & 187 \\
\hline & TOTAL & 243 \\
\hline
\end{tabular}

\subsection{The Financial Reporting Quality}

One of the most typical attributes of the financial reporting quality is accounting conservatism [19]. FASB No. 2 defines accounting conservatism as a prudent accounting treatment that is required for a company in the face of uncertainty and risks. Similarly, IFRS defines conservatism as prudence, and asserts that a careful accounting treatment should not overestimate earnings or underestimate expenses in uncertain circumstances. Accounting conservatism has been highly demanded by investors since the Enron scandal [20,21]. This also reflects the argument made by Watts [22], that the demand for accounting conservatism is strengthened by high litigation risk, regulation, and leverage.

A firm's earnings management has also generally been considered as the main determinant of financial reporting quality. Because earnings management is a typical way for managers to seek private interest, this engenders investors to opt for the adverse selection when they allocate their resources. While accounting fraud is regulated by law, it is almost impossible for GAAP to prohibit earnings management perfectly; managers attempt to maximize their private interest through earnings management. For example, they adjust the timing of sales and purchase, decomposition of assets, changing accounting policy, and extraordinary depreciation, and so on [23].

Research on earnings management and its incentives have been extensively conducted. The typical motivation for earnings management recognizes earnings smoothing [24], tax minimization [25-27], regulation [27-29], and manager compensation [30,31]. Watts and Zimmerman argue that earnings 
management is affected by the manager's compensation, the possibility of violation of debt covenant, and political cost [32].

In South Korea, there have been many studies on the behavior of earnings management and its possible motivation. Whang [23] reports that more than $80 \%$ of the companies conduct earnings management through the adjustment of business schedule. Song and Choi also examine the relationship between accounting change and earnings smoothing, and reports that companies conduct earnings management in order to make reported earnings come close to normal earnings or expected earnings [33].

Substantiated by such studies on the behavior of earnings management and conservatism, the economic consequences of the financial reporting quality in the corporate field have been actively investigated. More specifically, the cost of capital is one of the main elements that are affected by the financial reporting quality. Francis et al. examines how financial reporting quality is related to the cost of capital by investigating seven different attributes of the reporting quality [34]. Bhattacharya et al. also examine the relationship between the cost of capital and the transparency of accounting procedure across several countries [35]. Li and Richie report that a higher level of earnings smoothing may produce a lower cost of capital and a higher credit grade [36]. Ahmed et al. and Zhang also argue that the cost of capital is determined by the level of accounting conservatism [37,38]. In South Korea, Yang et al. and Park et al. report that the higher its level of earnings smoothing, the lower the company's credit level [39,40]. Finally, Jung and Yu [41] argue that accounting conservatism decreases the cost of capital from the stock market. These studies portray that earnings management, accounting conservatism, and accruals can affect the cost of capital.

As another aspect of financial reporting quality, value relevance of accounting information can be considered. Generally, the more relevant the accounting information is, the higher the financial reporting quality. Jianu et al. [42] studied empirically whether investors in the Romanian stock market perceive accounting information to be value-relevant and they obtained evidence of value relevance of accounting information based on the return and price model. When it comes to financial reporting quality, however, earnings management and accounting conservatism are usually used as a concept to evaluate firms' financial reporting quality.

\subsection{Development of Research Hypothesis}

As proven by the studies, we acknowledge that corporate ethics affects business activities. Norreen [9] argues that managerial behavior is affected by economic motivation as well as non-economic motivation. Schwepker and Ingram, Wimbush and Shepard, and Wimbush also suggest that corporate culture can yield certain ethical behaviors; further, it is deeply related to managerial unethical behaviors [10-12]. Based on this suggestion, we predict that corporate reporting activity is particularly affected by its level of ethics or managerial ethics. Such research direction is currently widespread due to the adoption of the business ethics system and demand for business ethics consciousness. Enron's scandal is one of the outstanding examples showing the importance of business ethics. Thus, Healy and Palepu [5] argue that the scandal is obviously an extreme case that shows a corporation's unethical behavior and illegality. In addition, Touche Ross [43] argues that the manager's tendency for short-term profits drives the corporation's unethical behavior and, as a result, financial reporting quality declines.

Meanwhile, SERI [44] reports that the adoption of ethical management increases accounting transparency. Moreover, Choi and Lee [45] examine the acceptability of ethics among accountants, such as CPAs, institutional investors, and treasurers. The result reveals that while treasurers are most generous of earnings management, CPAs and regulators are most conservative on earnings management. More specifically, it shows that a manager's attitude is most generous in terms of earnings management. This attitude implies that the financial reporting quality is affected by the level of managerial ethics. A more direct approach for suggesting that corporate and managerial ethics can affect the financial reporting quality is proposed by Moon [6] and Choi and Pae [7]. Moon [6] compares 
the firms that adopted the business ethics code with those that did not and shows how the adoption of such ethics code decreases the discretionary accruals. Choi and Pae [7] investigate the relation among ECI (Ethical Commitment Index), corporation's discretionary accruals, accounting conservatism, and accruals quality. As a result, when ECI is high, the level of discretionary accruals decreases with a high level of accounting conservatism. Based on the evidence that ethical management or level of ethics can affect the financial reporting quality, we provide the following hypotheses demonstrating that firms that have had fraud scandals would retain lower financial reporting quality, whereas firms with clean track records would hold higher financial reporting quality.

Hypothesis 1. Fraud firms have a lower level of accounting conservatism (CSCORE) than non-fraud firms.

\section{Research Design}

\subsection{Proxies for Financial Reporting Quality}

We adopt accounting conservatism (CSCORE: Basu [46]; Khan and Watts [47]), discretionary accruals (DA: Kothari [48]) and accruals quality (AQ: Dechow and Dichev [49]; McNichols [50]; Francis et al. [51]) as proxies for financial reporting quality, because financial reporting quality is highly related to managers' discretionary accounting choices.

\subsubsection{Accounting Conservatism (Khan and Watts [47]): CSCORE)}

We also measure CSCORE (Khan and Watts [47]) for firm-year level of accounting conservatism in order to show the relationship between the level of managerial ethics and financial reporting quality. We use Basu's model, which measures asymmetric timeliness in terms of earnings recognition, thereby representing the level of accounting conservatism. We have derived the coefficient values for each firm and year.

$$
X_{i, t}=\beta_{1, t}+\beta_{2, i, t} D_{i, t}+\beta_{3, i, t} R_{i, t}+\beta_{4, i, t} D_{i, t} * R_{i, t}+\varepsilon_{i, t}
$$

$X_{i, t}$ : Value of earnings before nonrecurring items divided by market value of equity for firm $i$

$D_{i, t}$ : If the adjusted annual stock return is below 0 , dummy has a value of 1 , otherwise 0

$R_{i, t}$ : Annual market adjusted stock return for firm $i$

Here, $i$ represents the firm, $t$ means the year and the earnings divided by market value is represented as $x . R$ is the cumulative market-adjusted return and $D$ is the dummy variable for a negative return. $\beta_{4, j, t}$ in Equation (1) is the incremental timeliness of bad news over good news. It shows a firm's accounting conservatism level by year. $\beta_{3, i, t}$ (timeliness of good news) and $\beta_{4, i, t}$ (conservatism) are coefficients indicating the timeliness of good news and the level of accounting conservatism by firm-year.

$$
\begin{aligned}
& \text { GSCORE } \equiv \beta_{3, i, t}=\mu_{i, t}+\mu_{2, t} M K V_{i, t}+\mu_{3, t} M B_{i, t}+\mu_{4, t} L E V_{i, t} \\
& \text { CSCORE } \equiv \beta_{4, i, t}=\lambda_{i, t}+\lambda_{2, t} M K V_{i, t}+\lambda_{3, t} M B_{i, t}+\lambda_{4, t} L E V_{i, t}
\end{aligned}
$$

$M K V_{i, t}:$ Log value of market value for firm $i$

$M B_{i, t}$ : Market value divided by book value for firm $i$

$L E V_{i, t}$ : Book value divided by debt for firm $i$

$M K V$ is the natural log value of the market value, $M B$ is the market-to-book ratio, and LEV is the debt-to-equity ratio. $\beta_{3, i, t}$ (timeliness of good news) and $\beta_{4, i, t}$ (conservatism) from Equation (1) are derived in Equations (2) and (3).

$$
\begin{gathered}
X_{i, t}=\beta_{1, t}+\beta_{2, t} D_{i, t}+R_{i, t}\left(\mu_{i, t}+\mu_{2, t} M K V_{i, t}+\mu_{3, t} M B_{i, t}+\mu_{4, t} L E V_{i, t}\right) \\
+D_{i, t} * R_{i, t}\left(\lambda_{i, t}+\lambda_{2, t} M K V_{i, t}+\lambda_{3, t} M B_{i, t}+\lambda_{4, t} L E V_{i, t}\right) \\
+\left(\delta_{1, t} M K V_{i, t}+\delta_{2, t} M B_{i, t}+\delta_{3, t} L E V_{i, t}+\delta_{4 t} D_{i, t} M K V_{i, t}+\delta_{5, t} D_{i, t} M B_{i, t}+\delta_{6, t} D_{i, t} L E V_{i, t}\right)+\varepsilon_{i, t}
\end{gathered}
$$


The coefficients in Equation (4) estimated by firm-industry and year are $\lambda_{1, t}, \lambda_{2, t}, \lambda_{3, t}$, and $\lambda_{4, t}$. They are later adopted to measure CSCORE. A greater CSCORE indicates a higher level of accounting conservatism. These coefficient values are tested by various accounting conservatism measures in Khan and Watts [47]. The result shows that CSCORE reliably represents the level of accounting conservatism. Thus, we expect that the asymmetric timeliness of earnings as financial reporting quality is related to managerial ethics.

\subsubsection{Discretionary Accruals (Modified Jones Model 1995; Kothari Model 2005)}

We adopt Kothari's model to mitigate the measurement error of the modified Jones Model (Dechow et al. [52]), which has been a method widely used to estimate discretionary accruals. Kothari's model (Kothari et al. [48]) estimates discretionary accruals by adjusting firm performance based on the modified Jones model. From this model, we estimate non-discretionary accruals (NDA) and then subtract NDA from the total accruals (note: NI-CFO). The final output from the calculation provides the discretionary accruals (DA).

$$
\begin{gathered}
A c c J M D A_{i, t}=\left(T A_{i, t} / A_{i, t-1}\right)-\left(\hat{\alpha_{0}}\left(\frac{1}{A_{i, t-1}}\right)+\hat{\alpha_{1}}\left[\frac{\Delta R E T_{i, t}-\Delta R E C_{i, t}}{A_{i, t-1}}\right]+\hat{\alpha_{2}}\left(\frac{P P E_{i, t}}{A_{i, t-1}}\right)\right. \\
\operatorname{AccKODA}_{i, t}=\left(T A_{i, t} / A_{i, t-1}\right)-\left(\hat{\beta_{0}}\left(\frac{1}{A_{i, t-1}}\right)+\hat{\beta_{1}}\left[\frac{\Delta R E T_{i, t}-\Delta R E C_{i, t}}{A_{i, t-1}}\right]+\hat{\beta_{2}}\left(\frac{P P E_{i, t}}{A_{i, t-1}}\right)+\hat{\beta_{3}} \text { lagged }\left(R O A_{i, t-1}\right)\right.
\end{gathered}
$$

$\operatorname{AccJMD} A_{i, t}$ : Discretionary accruals for firm $i$ at year $t$ by using the Modified-Jones Model (Dechow et al. 1995)

$A c c K O D A_{i, t}$ : Discretionary accruals for firm $i$ at year $\mathrm{t}$ by using Kothari et al.'s (2005) model

TACC $_{i, t-1}$ : Total accruals for firm $i$ at year $t-1$

$\triangle R E V_{i, t}$ : Change of sales at year $t: t-(t-1)$

$\triangle R E C_{i, t}$ : Change of account receivable at year $t: t-(t-1)$

$P P E_{i, t}: P P E$ for company $i$ at year $t$

lagged $(R O A)_{i, t-1}$ : Profitability of total assets: NI/TA

$A_{i, t-1}$ : Total assets at year $t-1$

We estimate NDA using firm-specific industry observation and cross-sectional analysis from the years 2005 to 2012 (DeFond and Jiambalvo [53]; Subramanyam [54]). During the period in the 2000s when economy expands, the time series stability is likely to be ruined. Hence, this seems to create a biased coefficient if we use the time series model to estimate non-discretionary accruals. Therefore, in this paper, we use DeFond and Jiambalvo [53] and Subramanyam's [54] model in order to protect the bias based on the cross-sectional model instead of the time-series model). The coefficients estimated from the regression are applied to Equations (5) and (6) in order to measure discretionary accruals; then, the estimated absolute value is used to gauge the level of earnings management.

\subsubsection{Accruals Quality}

Accruals quality is seen from the perspective that earnings are closely related to cash flow among all other financial reporting quality measures (Penman [55]; Harris et al. [56]). Dechow and Dichev [52] suggest a method that adopts a regression model, where current accruals are compared with the cash flow of the prior, current, and posterior periods. We adopt McNichols' [51] model, which is based on the Dechow and Dichev [52] model, in order to estimate accruals quality. We use the standard deviation of discretionary accruals for 5 years according to Dechow and Dichev [52]. Dechow and Dichev [52] argue that accruals quality is determined by the variation and uncertainty of accruals for a multiperiod. The accruals value for working capital is used for the regression on prior, current, and posterior period's cash flow. The unexplained portion in the equation is in a negative relationship with accruals quality. Francis et al. [50] argue that accruals quality fundamentally includes the comprehensive uncertainty of accruals. They also suggest that Dechow and Dichev's model may not precisely provide the total accruals because there can be effects of the past in the relation between non-current and realized cash 
flow. Therefore, we adopt the modified Dechow and Dichev model (McNichols [50]; Francis et al. [51]). McNichols [50] and Francis et al. [51] verified the high explanatory power of the cross-sectional Dechow and Dichev [52] model, which includes the Sales and PPE variables.)

$$
\frac{\text { CCA }_{i, t}}{\text { Assets }_{i, t}}=\varphi_{0, i}+\varphi_{1, i} \frac{\mathrm{CFO}_{i, t-1}}{\text { Assets }_{i, t}}+\varphi_{2, i} \frac{\mathrm{CFO}_{i, t}}{\text { Assets }_{i, t}}+\varphi_{3, i} \frac{\mathrm{CFO}_{i, t+1}}{\text { Assets }_{i, t}}+\varphi_{4, i} \Delta \operatorname{REV}_{i, t}+\varphi_{5} \text { PPE }_{i, t}+v_{i, t}
$$

$T C A_{i, t}$ : Total current accruals for firm $i$ at year $t$

Assets $i_{i, t}$ : Average total assets for firm $i$ at years $t$ and $t-1$

$C F O_{i, t}$ : Operating cash flow for firm $i$ at year $t$

$\triangle R E V_{i, t}$ : Sales subtracted by prior sales for a firm $i$ at year $t$

$P P E_{i, t}: P P E$ for firm $i$ at year $t$

$v_{i, t}$ : Residual value estimated from industry-year regression for firm $i$ at year $t$

We separate the KOSPI from the KOSDAQ market and classify 11 industry categories following prior studies. Further, we have conducted a cross-sectional regression from $t-4$ to $t$-year by firm-year according to Equation (7). Using the standard deviation for accruals for 5 years from the regression, we calculate accruals quality by multiplying the standard deviation by -1 .

\subsection{Research Model}

As mentioned above, we establish 3 different research models to test the relationship between managerial ethics and financial reporting quality. First of all, we establish the research model in order to verify the level of financial reporting quality with fraud firms in terms of embezzlement and dereliction of duty.

$$
\begin{aligned}
& A b s D A(R)_{i, t}=\alpha_{0}+\alpha_{1} \text { FRAUD }_{i, t}+\alpha_{2} \text { CFO }_{i, t}+\alpha_{3} S I Z E_{i, t}+\alpha_{4} L E V_{i, t} \\
& +\alpha_{5} M B_{i, t}+\alpha_{6} R E T_{i, t}+\alpha_{7} R O A_{i, t}+\alpha_{8} G R W_{i, t}+\alpha_{9} B I G 4_{i, t} \\
& +\alpha_{10} \operatorname{CSCORE}_{i, t}+\alpha_{11} \text { AccQual }_{i, t}+\alpha_{12} \text { INDUSD }_{t}+\alpha_{10} \text { YEARD }_{i}+\varepsilon_{i, t}
\end{aligned}
$$

AbsDA is the dependent variable representing the financial reporting quality. FRAUD is a dummy variable for fraud firms, which is our main focus. The control variables are operation cash flow (CFO), prior total accruals (TACC), prior debt-to-equity ratio, growth ratio (GRW; GRW indicates the growth rate of total asset of a company), auditing quality (BIG4; Big4 includes Ernst \& Young Global Limited, Samjong KPMG, Deloitte Anjin and Samil PWC), market dummy (Market; The Korean stock market is divided into KOSPI and KOSDAQ), industry dummy (INDUS) (Using Guide 5 provided in FnGuide, we establish the 12 categories of industry. In this paper, we only use a total of 11 industry groups, omitting the financial industry, for analysis) and year dummy (YEAR).

Dechow et al. [49] report that the estimation error of current accruals is the result of the distorted behavior of managers' opportunistic reporting activity. They argue that the main factor of earnings management is operating cash flows. Therefore, we select the prior total accruals in order to control for the reverse effects of discretionary accruals. LEV is selected as a control variable because it has an incentive for earnings management, particularly when a high debt-to-equity ratio firm is faced with a risk of debt covenant violation (DeFond and Jiambalvo [53]; Hageman and Zmijewski [57]). Also, the growth variable (GRW) is selected because the high growth rate of firms can lead to earnings management Yoon [58]. Kim et al. [59] report that high audit quality can control managers' opportunistic behaviors and also, the firm can retain a more conservative attitude in applying and interpreting accounting rules. Therefore, we include the auditing quality variable (BIG4), size, industry, and year as the control variables. Finally, we include the market dummy as the last control variable because each stock market has its unique attributes.

The main purpose of this paper is to find the relationship between fraud firms and the absolute value of discretionary accruals. We expect a fraud firm to have a greater absolute value of discretionary accruals (AbsDA) than a non-fraud firm. 
We then establish the second research model in order to test the hypothesis that fraud firms have lower levels of accounting conservatism (CSCORE) than non-fraud firms.

$$
\begin{gathered}
\operatorname{CSCORE}_{i, t}=\alpha_{0}+\alpha_{1} \text { FRAUD }_{i, t}+\alpha_{2} \text { CFO }_{i, t}+\alpha_{3} \text { SIZE }_{i, t}+\alpha_{4} L E V_{i, t} \\
+\alpha_{5} M B_{i, t}+\alpha_{6} \text { RET }_{i, t}+\alpha_{7} \text { ROA }_{i, t}+\alpha_{8} \operatorname{GRW}_{i, t}+\alpha_{9} B I G 4_{i, t} \\
+\alpha_{10} \text { AccKODA }_{i, t}+\alpha_{11} \text { AccQual }_{i, t}+\alpha_{12} \text { INDUSD }_{t}+\alpha_{10} Y E A R D_{i}+\varepsilon_{i, t}
\end{gathered}
$$

Equation (9) above shows the relationship between fraud and accounting conservatism. It establishes CSCORE as the dependent variable, and fraud dummy (FRAUD), ROA, growth rate (GRW), audit quality (BIG4), market dummy (MARKET), industry dummy (INDUS) and year dummy (YEAR) as the independent variables. Whang et al. [23] assume that firms with high quality audit are likely to have high levels of accounting conservatism; further, they report that firms audited by BIG4 tend to display more conservatism in their accounting customs. Therefore, we include BIG4 as a control variable.

We establish Equation (10) in order to test the third hypothesis, that fraud firms have lower accruals quality $(\mathrm{AQ})$ than non-fraud firms.

$$
\begin{gathered}
\text { AccQual }_{i, t}=\alpha_{0}+\alpha_{1} \text { FRAUD }_{i, t}+\alpha_{2} \text { CFO }_{i, t}+\alpha_{3} \text { SIZE }_{i, t}+\alpha_{4} L E V_{i, t} \\
+\alpha_{5} M B_{i, t}+\alpha_{6} \operatorname{RET}_{i, t}+\alpha_{7} \text { ROA }_{i, t}+\alpha_{8} \text { GRW }_{i, t}+\alpha_{9} B I G 4_{i, t} \\
+\alpha_{10} \text { AbsKODA }_{i, t}+\alpha_{11} \text { CSCORE }_{i, t}+\alpha_{12} \text { INDUSD }_{t}+\alpha_{10} \text { YEARD }_{i}+\varepsilon_{i, t}
\end{gathered}
$$

Equation (10) explores the relationship between managerial ethics level and financial reporting quality. We adopt accruals quality as the dependent variable. The dependent variable of this equation is AQ (accruals quality), measured by Dechow and Dichev's [52] model. The FRAUD variable is the interesting variable. To investigate the relationship, we use the same control variables as in Equations (8) and (9).

\section{Sample and Result}

\subsection{Sample}

We extracted the sample in order to conduct an empirical analysis over the period of 2005-2012. In this paper, we set the research period from 2005 to 2012 because data was provided since 2005 and we included only the firms that closed an account in December. Also, as the proxy of corporate ethics, we collected the sample of fraud firms from firms that were convicted of embezzlement and dereliction of duty. Table 2 shows the distribution of the fraud sample by year; 56 fraud firms belonged to KOSPI, and the remaining (187 fraud firms) to KOSDAQ. We use all the 14,361 firm-year observations and also created a benchmark group which was selected based on the same industry category and similar size with firms that were not involved in embezzlement and dereliction of duty as the control group over the years 2005-2012. The results of Table 1 show that the overall frequency of fraud is uniform. Fraud cases in KOSDAQ were three times as frequent as those in KOSPI due to the lower listing requirements. Consequently, we interpret that the KOSPI market may be healthier than the KOSDAQ market.

The number of samples for embezzlement and dereliction of duty was excluded for firms which experienced both cases more than twice in the same year.

We collect data by using the Data Guide5 that is provided by FNGuide. A fraud firm's data is obtained from the KRX's KIND in order to estimate the absolute value of discretionary accruals, accounting conservatism and accruals quality.

Table 2 suggests the statistics of the main variables. The modified Jones Model and the Kothari model with added ROA, which is based on the modified Jones model, shows the absolute discretionary accruals (AbsDA) with a mean value of 0.148 and 0.144 . The CSCORE based on Khan and Watts [47] show a mean value of 0.326 . The mean value of accruals quality is -0.138 . The mean value of operating cash flow is 0.028 and leverage at 0.486 . 
Table 2. Descriptive of main Variables.

\begin{tabular}{cccccc}
\hline Variable & Obs & Mean & Std. Dev. & Min & Max \\
\hline CSCORE $_{i, t}$ & 12,341 & 0.326 & 0.678 & -24.547 & 6.315 \\
AccJMDA $_{i, t}$ & 14,155 & 0.148 & 0.256 & 0.000 & 8.084 \\
AccKODA $_{i, t}$ & 14,155 & 0.144 & 0.254 & 0.000 & 8.092 \\
AccQual $_{i, t}$ & 12,799 & -0.138 & 0.211 & -5.551 & 0.000 \\
CFO & $14, t$ & 0.028 & 0.269 & -18.207 & 8.258 \\
SIZE $E_{i, t}$ & 14,361 & 8.027 & 0.642 & 4.072 & 11.125 \\
$L E V_{i, t}$ & 14,361 & 0.486 & 3.497 & 0.001 & 346.803 \\
$M B_{i, t}$ & 12,483 & 1.416 & 9.188 & -878.482 & 192.819 \\
$R E T_{i, t}$ & 12,483 & 0.076 & 0.847 & -10.565 & 31.845 \\
$R O A_{i, t}$ & 14,361 & -0.053 & 1.265 & -137.182 & 10.979 \\
$G R W_{i, t}$ & 14,155 & 0.671 & 55.414 & -0.996 & 6590.844 \\
\hline
\end{tabular}

This table shows descriptive statistics for the variables used in the main regression analyses. The number of the sample based on research data for the main dependent variables (DisAcc) is 4038 firm-year observations from 2001 to 2012. Also, we exclude the value of non-useful information such as the main independent variable DisAcc.

\subsection{Result}

\subsubsection{Main Result of Regression}

The main aspect of this model is the relationship between accounting conservatism and financial reporting quality. To test the relationship, we use CSCORE, which represents accounting conservatism, and FRAUD dummy variable, which indicates the level of managerial ethics.

Sadly, the result from Table 3 shows that CSCORE and FRAUD variables have an insignificant relationship, which is inconsistent with the second hypothesis. The main result of the pooled regression suggests -0.012 ( $\mathrm{t}$-value: -0.590 ), and the matched regression shows 0.012 ( $\mathrm{t}$-value: 0.380 ). Thus, this does not satisfy our prior expectation. In terms of the results for other control variables, leverage (LEV), market to book ratio (MB), stock return (RET) and growth ratio (GRW) have a positive relationship with reporting quality, as represented by CSCORE. Because a higher growth rate causes higher information asymmetry, it requires strong accounting conservatism (LaFond and Watts [60]). On the other hand, our result contradicts the suggestion that higher auditing quality leads to strong accounting conservatism. Thus, we suggest that this relationship be tested again.

Table 3. The Relationship between Managerial Ethics and Accounting Conservatism.

\begin{tabular}{|c|c|c|c|c|c|c|c|c|}
\hline \multicolumn{9}{|c|}{$\begin{array}{c}\operatorname{CSCORE}_{i, t}=\alpha_{0}+\alpha_{1} \text { FRAUD }_{i, t}+\alpha_{2} \text { CFO }_{i, t}+\alpha_{3} \operatorname{SIZE}_{i, t}+\alpha_{4} L E V_{i, t}+\alpha_{5} M_{i_{i, t}}+\alpha_{6} R E T_{i, t}+ \\
\alpha_{7} \text { ROA }_{i, t}+\alpha_{8} \text { GRW }_{i, t}+\alpha_{9} \text { BIG4 }_{i, t}+\alpha_{10} \text { AccKODA }_{i, t}+\alpha_{11} \text { AccQual }_{i, t}+\alpha_{12} \text { INDUSD }_{t}+\alpha_{10} Y E A R D_{i}+\varepsilon_{i, t}\end{array}$} \\
\hline & \multicolumn{4}{|c|}{ Main Regression (Column 1) } & \multicolumn{4}{|c|}{ 2SLS (Column 2) } \\
\hline \multirow[b]{2}{*}{ CSCORE } & \multicolumn{2}{|c|}{ PooledREG } & \multicolumn{2}{|c|}{ MatchedREG } & \multicolumn{2}{|c|}{ PooledREG } & \multicolumn{2}{|c|}{ MatchedREG } \\
\hline & Coef. & T-Value & Coef. & T-Value & Coef. & T-Value & Coef. & T-Value \\
\hline$F_{R A U D_{i, t}}$ & -0.012 & -0.590 & 0.012 & 0.380 & 0.319 & 2.370 & 0.800 & 2.600 \\
\hline$C F O_{i, t}$ & -0.134 & -9.010 & -0.076 & -1.930 & -0.223 & -13.490 & -0.067 & -1.690 \\
\hline$S I Z E_{i, t}$ & -0.957 & -162.630 & -0.774 & -20.070 & -0.952 & -146.730 & -0.756 & -19.390 \\
\hline$L E V_{i, t}^{i, t}$ & 0.143 & 13.400 & -0.030 & -0.770 & 0.221 & 18.250 & -0.031 & -0.790 \\
\hline$M B_{i, t}$ & 0.025 & 89.050 & 0.025 & 23.930 & 0.025 & 90.820 & 0.026 & 24.670 \\
\hline$R E T_{i, t}^{i, v}$ & 0.091 & 21.380 & 0.044 & 2.480 & 0.100 & 21.170 & 0.047 & 2.580 \\
\hline$R O A_{i, t}^{i, t}$ & 0.243 & 28.750 & 0.169 & 7.150 & 0.266 & 29.250 & 0.161 & 6.710 \\
\hline$G R W_{i, t}$ & 0.010 & 5.750 & 0.054 & 3.040 & 0.009 & 5.020 & 0.065 & 3.070 \\
\hline$B I G 4_{i, t}$ & -0.057 & -9.550 & -0.086 & -2.220 & -0.050 & -7.630 & -0.083 & -2.080 \\
\hline $\operatorname{AccKODA}_{i, t}$ & 0.064 & 5.310 & 0.017 & 0.490 & 0.064 & 4.590 & 0.003 & 0.080 \\
\hline $\operatorname{Acc} Q u a l_{i, t}$ & 0.150 & 10.900 & 0.045 & 1.230 & 0.186 & 12.100 & 0.076 & 1.890 \\
\hline
\end{tabular}


Table 3. Cont.

\begin{tabular}{|c|c|c|c|c|}
\hline \multicolumn{5}{|c|}{$\begin{array}{c}\operatorname{CSCORE}_{i, t}=\alpha_{0}+\alpha_{1} \text { FRAUD }_{i, t}+\alpha_{2} \text { CFO }_{i, t}+\alpha_{3} \operatorname{SIZE}_{i, t}+\alpha_{4} L E V_{i, t}+\alpha_{5} M B_{i, t}+\alpha_{6} R E T_{i, t}+ \\
\alpha_{7} R_{\text {ROA }}+\alpha_{i, t}+\alpha_{8} \text { GRW }_{i, t}+\alpha_{9} \text { BIG4 }_{i, t}+\alpha_{10} \text { AccKODA }_{i, t}+\alpha_{11} \text { AccQual }_{i, t}+\alpha_{12} \text { INDUSD }_{t}+\alpha_{10} Y E A R D_{i}+\varepsilon_{i, t}\end{array}$} \\
\hline InudsD & Included & Included & Included & Included \\
\hline YearD & Included & Included & Included & Included \\
\hline F-value & 2024.010 & 81.380 & 1868.36 & 80.25 \\
\hline Adj R-squared & 0.826 & 0.843 & 0.827 & 0.848 \\
\hline Number of obs & 11,939 & 405 & 10,545 & 370 \\
\hline
\end{tabular}

This table presents results from the regression analyses (H2) of the effect of a firm's ethical behavior on a firm's accounting conservatism. Our main independent variable is FRAUD, and the dependable variable is CSCORE. Across all of the regressions, we take $\mathrm{N}=11,939$ using firm-year observations from 2005 to 2012 . We suggest coefficient estimates with $t$-value, only significant if $t$-value $>|2|$. Column 1 shows the coefficient value of FRAUD as the proxy of a firm's ethical behavior, wherein the dependent variable is CSCORE as the proxy of a firm's accounting conservatism. Column 2 shows the coefficient value of 2SLS, wherein the independent variable is FRAUD as the proxy of a firm's ethical behavior with the dependent variable CSCORE, representing a firm's accounting conservatism. In addition, we attempt the pooled and matched regression for each model to derive more robust results.

\subsubsection{Additional Analysis}

We also established the following hypotheses to investigate whether they conform with prior research results. Two additional analyses have been conducted. One is for testing whether

Hypothesis 2. Fraud firms have greater discretionary accruals (DA) than non-fraud firms.

and the other is for testing whether

Hypothesis 3. Fraud firms have lower accruals quality $(A Q)$ than non-fraud firms.

First, Table 4 shows the relationship between absolute value of discretionary accruals (AbsDA) and fraud firm (FRAUD) variables. Panel A in Table 4 provides the results of absolute discretionary accruals, modified from the Jones Model and Kothari's Model with pooled and matched regression. The result shows that the coefficients of AbsJMDA in the pooled and matched regression are 0.134 (t-value: 9.040) and 0.092 (t-value: 2.020), both significant. Also, the results from AbsKODA with the regression are 0.139 ( $\mathrm{t}$-value: 9.340 ) and 0.092 ( $\mathrm{t}$-value: 2.000 ), both significant. Panel B in Table 3 suggests the results of absolute discretionary accruals, modified from the Jones Model and Kothari's Model with pooled and matched 2SLS regression. In this paper, we assume there is a simultaneous relationship between a firm's ethics level and reporting qualities; therefore, we attempt the 2SLS to solve endogeneity problems that can be generated from the simultaneous relationship. We replace the FRAUD variable with its estimated coefficient value in each main model. First, we attempt the first regression to predict an estimated value of FRAUD, as follows, and then we adopt the estimated value of the FRAUD variable in the main model. FRAUD $D_{i, t}=\gamma_{0}+\gamma_{1} F R A U D_{i, t-1}+\gamma_{2} S I Z E_{i, t}+\gamma_{3} L E V_{i, t}+$ $\gamma_{4}$ Market $_{i, t}+\gamma_{5} G R W_{i, t}+\gamma_{6} B I G 4_{i, t}+\gamma_{7} R O A_{i, t}+\varepsilon_{i, t}$ (First Stage) The result shows that the coefficients of AbsJMDA in the pooled and matched regression are 0.587 (t-value: 6.280) and 1.018 (t-value: 2.430), both significant. Also, the results from AbsKODA with the regression are 0.539 (t-value: 5.760 ) and 0.929 ( $t$-value: 2.170 ), also both significant. Therefore, we find the relationship to be consistent with the first hypothesis. We realize that firms with low levels of managerial ethics display opportunistic behaviors in terms of reporting activity, and that this attitude has to do with the decrease in the reporting quality and financial reporting transparency. 
Table 4. Main Result of Earnings Quality.

\begin{tabular}{|c|c|c|c|c|c|c|c|c|}
\hline \multicolumn{9}{|c|}{ Panel A: Discretionary Accruals by Jones Model and Kothari Model. } \\
\hline & \multicolumn{4}{|c|}{ AbsJMDA (Column 1) } & \multicolumn{4}{|c|}{ AbsKODA (Column 2) } \\
\hline & \multicolumn{2}{|c|}{ PooledREG } & \multicolumn{2}{|c|}{ MatchedREG } & \multicolumn{2}{|c|}{ PooledREG } & \multicolumn{2}{|c|}{ MatchedREG } \\
\hline & Coef. & T-Value & Coef. & T-Value & Coef. & T-Value & Coef. & T-Value \\
\hline FRAUD $_{i, t}$ & 0.134 & 9.040 & 0.092 & 2.020 & 0.139 & 9.340 & 0.092 & 2.000 \\
\hline$C F O_{i, t}$ & 0.273 & 24.530 & 0.301 & 5.290 & 0.263 & 23.590 & 0.289 & 5.020 \\
\hline$S I Z E_{i, t}$ & 0.022 & 2.760 & -0.047 & -0.570 & 0.022 & 2.670 & -0.038 & -0.460 \\
\hline$L E V_{i, t}$ & 0.028 & 3.460 & 0.114 & 1.960 & 0.035 & 4.240 & 0.134 & 2.270 \\
\hline$M B_{i, t}$ & -0.001 & -2.670 & 0.000 & -0.130 & -0.001 & -2.290 & 0.000 & -0.040 \\
\hline$R E T_{i, t}^{i, v}$ & -0.013 & -4.020 & -0.056 & -2.120 & -0.012 & -3.540 & -0.059 & -2.210 \\
\hline$R O A_{i, t}$ & -0.264 & -42.300 & -0.245 & -6.870 & -0.250 & -39.970 & -0.229 & -6.360 \\
\hline$G R W_{i, t}$ & 0.034 & 25.910 & 0.219 & 8.950 & 0.032 & 24.540 & 0.222 & 9.010 \\
\hline$B I G 4_{i, t}$ & -0.011 & -2.370 & 0.058 & 1.010 & -0.010 & -2.290 & 0.054 & 0.930 \\
\hline $\operatorname{CSCORE}_{i, t}$ & 0.038 & 5.500 & 0.029 & 0.380 & 0.037 & 5.310 & 0.038 & 0.490 \\
\hline AccQual $_{i, t}$ & -0.203 & -19.650 & -0.260 & -4.870 & -0.217 & -21.030 & -0.263 & -4.870 \\
\hline InudsD & Included & & Included & & Included & & Included & \\
\hline YearD & Included & & Included & & Included & & Included & \\
\hline F-value & 210.090 & & 16.620 & & 200.920 & & 15.970 & \\
\hline Adj R-squared & 0.329 & & 0.511 & & 0.319 & & 0.500 & \\
\hline Number of obs & 11,939 & & 405 & & 11,939 & & 405 & \\
\hline \multicolumn{9}{|c|}{ Panel B: Discretionary Accruals by Jones Model and Kothari Model with 2SLS Method } \\
\hline & \multicolumn{4}{|c|}{ AbsJMDA (Column 1) } & \multicolumn{4}{|c|}{ AbsKODA (Column 2) } \\
\hline & \multicolumn{2}{|c|}{ PooledREG } & \multicolumn{2}{|c|}{ MatchedREG } & \multicolumn{2}{|c|}{ PooledREG } & \multicolumn{2}{|c|}{ MatchedREG } \\
\hline & Coef. & T-Value & Coef. & T-Value & Coef. & T-Value & Coef. & T-Value \\
\hline FRAUDHAT ${ }_{i, t}$ & 0.587 & 6.280 & 1.018 & 2.430 & 0.539 & 5.760 & 0.929 & 2.170 \\
\hline$C F O_{i, t}$ & 0.297 & 26.410 & 0.288 & 5.570 & 0.286 & 25.400 & 0.276 & 5.230 \\
\hline$S I Z E_{i, t}$ & 0.026 & 3.260 & -0.024 & -0.310 & 0.024 & 3.100 & -0.017 & -0.220 \\
\hline$L E V_{i, t}$ & 0.040 & 4.710 & 0.107 & 2.000 & 0.047 & 5.570 & 0.126 & 2.310 \\
\hline$M B_{i, t}$ & 0.000 & -1.920 & 0.001 & 0.400 & 0.000 & -1.570 & 0.001 & 0.420 \\
\hline$R E T_{i, t}$ & -0.018 & -5.510 & -0.082 & -3.320 & -0.016 & -4.840 & -0.085 & -3.410 \\
\hline$R O A_{i, t}$ & -0.268 & -44.110 & -0.217 & -6.560 & -0.254 & -41.830 & -0.204 & -6.050 \\
\hline$G R W_{i, t}$ & 0.027 & 22.580 & 0.193 & 7.100 & 0.025 & 21.220 & 0.200 & 7.210 \\
\hline$B I G 4_{i, t}$ & -0.003 & -0.720 & 0.010 & 0.170 & -0.003 & -0.730 & 0.010 & 0.190 \\
\hline $\operatorname{CSCOR}_{i, t}$ & 0.032 & 4.770 & -0.007 & -0.090 & 0.031 & 4.590 & 0.006 & 0.080 \\
\hline $\operatorname{AccQual}_{i, t}$ & -0.188 & -17.810 & -0.125 & -2.310 & -0.207 & -19.640 & -0.131 & -2.370 \\
\hline InudsD & Included & & Included & & Included & & Included & \\
\hline YearD & Included & & Included & & Included & & Included & \\
\hline F-value & 232.940 & & 15.150 & & 222.170 & & 14.25 & \\
\hline Adj R-squared & 0.373 & & 0.499 & & 0.362 & & 0.4829 & \\
\hline Number of obs & 10,545 & & 370 & & 10,545 & & 370 & \\
\hline
\end{tabular}

This table presents results from the regression analyses (H1) of the effect of a firm's ethical behavior on a firm's earnings management. Our main independent variable is FRAUD, and dependent variables are AbsJMDA and AbsKODA. Across all of the regressions, we take $\mathrm{N}=10,545$ using firm-year observations from 2005 to 2012 . We suggest coefficient estimates with t-value, only significant if $t$-value $>|2|$. Column 1 in Panel A shows the coefficient value of FRAUD as the proxy of a firm's ethical behavior, wherein the dependent variable is AbsJMDA as the proxy of a firm's earnings management behavior. Column 2 in panel A presents the results from similar regression analyses as Column 1, with a firm's earnings management behavior estimated with AbsKODA. Column 1 in Panel B shows the coefficient value of 2SLS, wherein the independent variable is FRAUD as the proxy of a firm's ethical behavior with the dependent variable AbsJMDA, representing a firm's earnings management. Column 2 in panel B presents the results from similar regression analyses as Column 1 with a firm's earnings management behavior estimated with AbsKODA. In addition, we attempt the pooled and matched regression for each model to derive more robust results. 
In other words, this result suggests that firms with a record of embezzlement and dereliction of duty issue tend to hold a lower reporting quality. Among the control variables for testing the relationship between managerial ethics and reporting quality (AbsJMDA \& AbsKODA), operating cash flow (CFO) and auditing quality (BIG4) are found to be significant. This is consistent with Dechow and Dichev's argument, that cash flow is the main determinant of earnings management behavior. It is also consistent with Kim et al.'s [59] suggestion, that higher auditing quality can play a role in controlling managers' opportunistic behaviors.

Table 4 is the result of the regression analysis, depicting the relationship between managerial ethics and the absolute value of discretionary accruals (AbsJMDA \& AbsKODA).

Table 4 The Relationship between Managerial Ethics and Discretionary Accruals

$$
\begin{gathered}
\operatorname{AbsDA}(R)_{i, t}=\alpha_{0}+\alpha_{1} \text { FRAUD }_{i, t}+\alpha_{2} \text { CFO }_{i, t}+\alpha_{3} \text { SIZE }_{i, t}+\alpha_{4} L E V_{i, t} \\
+\alpha_{5} M B_{i, t}+\alpha_{6} \text { RET }_{i, t}+\alpha_{7} \text { ROA }_{i, t}+\alpha_{8} \text { GRW }_{i, t}+\alpha_{9} \text { BIG4 }_{i, t} \\
+\alpha_{10} \text { CSCORE }_{i, t}+\alpha_{11} \text { AccQual }_{i, t}+\alpha_{12} \text { INDUSD }_{t}+\alpha_{10} Y E A R D_{t}+\varepsilon_{i, t}
\end{gathered}
$$

Finally, Table 5 shows the relationship between accruals quality and the level of managerial ethics from the regression results. We also use operating cash flow (CFO), firm size (SIZE), leverage (LEV), profit ratio (ROA), growth ratio (GRW), auditing quality dummy (BIG4), industry dummy (INDUS)

\begin{tabular}{|c|c|c|c|c|c|c|c|c|}
\hline \multirow[b]{3}{*}{ AccQual } & \multicolumn{4}{|c|}{ Main Regression (Column 1) } & \multicolumn{4}{|c|}{ 2SLS (Column 2) } \\
\hline & \multicolumn{2}{|c|}{ PooledREG } & \multicolumn{2}{|c|}{ MatchedREG } & \multicolumn{2}{|c|}{ PooledREG } & \multicolumn{2}{|c|}{ MatchedREG } \\
\hline & Coef. & T-Value & Coef. & T-Value & Coef. & T-Value & Coef. & T-Value \\
\hline FRAUD $_{i, t}$ & -0.115 & -8.860 & -0.055 & -1.290 & -1.178 & -13.990 & -1.274 & -3.090 \\
\hline$C F O_{i, t}$ & 0.122 & 12.330 & 0.107 & 1.940 & 0.146 & 14.030 & 0.087 & 1.640 \\
\hline$S I Z E_{i, t}$ & 0.115 & 16.630 & 0.259 & 3.400 & 0.101 & 14.340 & 0.249 & 3.330 \\
\hline$L E V_{i, t}$ & -0.026 & -3.620 & 0.082 & 1.500 & -0.054 & -6.990 & 0.052 & 0.970 \\
\hline$M B_{i, t}$ & -0.002 & -8.410 & -0.001 & -0.320 & -0.002 & -9.730 & -0.003 & -1.270 \\
\hline$R E T_{i, t}^{i, t}$ & 0.012 & 4.230 & 0.015 & 0.600 & 0.012 & 4.050 & 0.018 & 0.720 \\
\hline$R O A_{i, t}^{, t}$ & -0.057 & -9.940 & -0.046 & -1.310 & -0.080 & -13.570 & -0.046 & -1.340 \\
\hline$G R W_{i, t}$ & -0.004 & -3.500 & -0.062 & -2.500 & -0.002 & -2.040 & -0.071 & -2.490 \\
\hline$B I G 4_{i, t}$ & 0.029 & 7.260 & 0.070 & 1.300 & 0.015 & 3.590 & 0.070 & 1.310 \\
\hline $\operatorname{AccKODA}_{i, t}$ & -0.165 & -21.030 & -0.225 & -4.870 & -0.171 & -19.640 & -0.123 & -2.370 \\
\hline CSCORE $E_{i, t}$ & 0.066 & 10.900 & 0.088 & 1.230 & 0.074 & 12.100 & 0.137 & 1.890 \\
\hline InudsD & Included & & Included & & Included & & Included & \\
\hline YearD & Included & & Included & & Included & & Included & \\
\hline F-value & 108.520 & & 5.990 & & 116.500 & & 4.550 & \\
\hline Adj R-squared & 0.201 & & 0.250 & & 0.228 & & 0.200 & \\
\hline Number of obs & 11,939 & & 405 & & 10,545 & & 370 & \\
\hline
\end{tabular}
and year dummy (YEAR) as the control variables.

Table 5. Main Result of Accruals Quality.

This table presents results from the regression analyses (H3) of the effect of a firm's ethical behavior on a firm's accruals quality. Our main independent variable is FRAUD, and the dependable variable is AccQual. Across all of the regressions, we take $\mathrm{N}=11,939$ using firm-year observations from 2005 to 2012. We suggest coefficient estimates with $t$-value, only significant if $t$-value $>|2|$. Column 1 shows the coefficient value of FRAUD as the proxy of a firm's ethical behavior, wherein the dependent variable is AccQual as the proxy of a firm's accruals quality. Column 2 shows the coefficient value of 2SLS, wherein the independent variable is FRAUD as the proxy of a firm's ethical behavior with the dependent variable AccQual, representing a firm's accruals quality. In addition, we attempt the pooled and matched regression for each model to derive more robust results.

Table 5 The Relationship between Managerial Ethics and Accruals Quality

$$
\begin{gathered}
\text { AccQual }_{i, t}=\alpha_{0}+\alpha_{1} \text { FRAUD }_{i, t}+\alpha_{2} \text { CFO }_{i, t}+\alpha_{3} \text { SIZE }_{i, t}+\alpha_{4} L E V_{i, t} \\
+\alpha_{5} M B_{i, t}+\alpha_{6} \text { RET }_{i, t}+\alpha_{7} R O A_{i, t}+\alpha_{8} G R W_{i, t}+\alpha_{9} B I G 4_{i, t} \\
+\alpha_{10} \text { AbsKODA }_{i, t}+\alpha_{11} \text { CSCORE }_{i, t}+\alpha_{12} \text { INDUSD }_{t}+\alpha_{10} Y E A R D_{i}+\varepsilon_{i, t}
\end{gathered}
$$


Table 5 suggests that accruals quality (AQ) is significantly negatively related to a firm's practice of fraud. First, in $\langle$ Column A $>$, we identify a negative relationship between a firm's ethics and reporting quality ((Pooled: (Coef: -0.115 , $\mathrm{t}$-value: -8860$)$, Matched: (Coef: $-0.055, \mathrm{t}$-value: -1.290$)$ ). Also, we suggest the result of 2SLS, which shows a strong negative relationship between a firm's ethics and reporting quality ((Pooled: (Coef: -1.178 , t-value: $-13,990)$, Matched: (Coef: -1.274 , $\mathrm{t}$-value: -3.090$)$ ). This indicates that fraud firms have a lower reporting quality than other company or benchmark firms. We interpret this result as the lower level of managerial ethics leading to lower financial reporting quality. Among the control variables, auditing quality (BIG4) has a positive relationship with accruals quality (AQ). Column A and Column B in Table 4 show that the relationship between accounting conservatism and auditing quality (BIG4) is positive. Thus, we leap to the conclusion that higher accounting conservatism (CSCORE) leads to higher accrual quality (AQ).

Overall, it is shown that discretionary accruals (DA: +) and accruals quality (AQ: -) significantly depend on the level of managerial ethics. On the other hand, Table 3 does not strongly suggest that accounting conservatism has any connection to a firm's ethics. This suggests that the reporting qualities depend on the level of managerial ethics. Therefore, we conclude that the level of managerial ethics is the primary determinant of reporting quality.

\subsubsection{Robustness Check}

For robustness check, we also attempt the panel regression to control fixed-effect and random-effect. The panel regression for panel data is a useful method to control the heterogeneity of reporting quality for individual firm $i$ and dynamic change of all the firms' accounting quality The fixed-effect model assumes that the slope parameter of explanatory variables is fixed through all the periods and firms, and individual firms' reporting quality level (intercept) may differ. On the other hand, the random-effect model assumes that the intercept difference is in stochastic relation. According to Jianu et al. [61], we conducted the Hausman test to know which is the best-fit model. As a result, either random or fixed effects model was not shown to be better than the other one).

Although we do not represent the tables, the panel regression analysis depicts the relationship between managerial ethics and a firm's reporting qualities such as accounting conservatism (CSCORE), the absolute value of discretionary accruals (AbsJMDA \& AbsKODA) and accruals quality (AccQual). The result shows that the coefficients of CSCORE in the pooled, fixed-effect regression, and random-effect regression are, respectively, 0.007 ( $\mathrm{t}$-value: 0.420 ) and 0.001 ( $\mathrm{t}$-value: 0.050 ), both significant. In addition, the coefficients of AbsKODA from the pooled, fixed-effect regression, and random-effect regression are shown to be, respectively, 0.086 (t-value: 5.250) and 0.126 (t-value: 8.410 ), both significant. Finally, the result shows that the coefficients of AccQual in the pooled, fixed-effect regression, and random-effect regression are, respectively, -0.048 ( $\mathrm{t}$-value: -4.910$)$ and -0.066 ( $\mathrm{t}$-value: -6.780 ), both significant. This indicates that reporting quality depends on the level of managerial ethics, as suggested in Tables $3-5$.

\section{Conclusions}

Recently, corporate ethics has been recognized as the main factor that influences a firm's performance. In addition, managers' acts according to their incentives were also found to affect financial reporting quality because they play the most important role when the firm adopts any accounting policy. From the same standpoint as the prior literature, we examine the assertion that the level of managerial ethics would affect the financial reporting quality. While we do not find a significant relationship between ethical behavior and accounting conservatism, the results show that lower levels of managerial ethics lead to higher levels of discretionary accruals. It also suggests that lower levels of managerial ethics tend to accompany weaker accruals quality. Overall, the results suggest that both corporate ethics and managerial ethics can affect a firm's financial reporting quality.

Our paper contributes in the following aspects. First, this study expands the perspective in the accounting field more generally, because still, only the relationship between accounting fraud and 
financial reporting quality has been tested. Second, we adopt more realistic corporate ethics criteria to test the relationship between corporate ethics and financial reporting quality by using a fraud firm sample, whereas related studies, such as Choi and Pae [7] and Moon [6], use ECI or existing corporate ethics codes. Finally, this paper is likely to contribute to the studies of cost of capital because we assume that the level of corporate ethics or managerial ethics can be reflected in their financing activities, which involve investors as well as potential investors.

In addition, we hope that regulators can establish a system in order to improve the level of corporate ethics based on our results. If a firm follows the system sincerely, then it can enhance the members' ethical consciousness as well as its competitiveness in the market by saving the cost of capital.

Author Contributions: C.I. and G.N. conceived and designed the study; C.I. collected data and analyzed them. G.N. discussed the implications and gave comments for publication.

Funding: This work was supported by Hankuk University of Foreign Studies Research Fund.

Conflicts of Interest: The authors declare no conflict of interest.

\section{References}

1. Freestone, O.; McGoldrick, P. Motivations of the Ethical Consumer. J. Bus. Ethics 2008, 79, 445-467. [CrossRef]

2. Jianu, I.; Turlea, C.; Gusatu, I. The Reporting and Sustainable Business Marketing. Sustainability 2016, 8, 23. [CrossRef]

3. Jones, T. Ethical Decision Making by Individuals in Organizations: An Issue-Contingent Model. Acad. Manag. Rev. 1991, 16, 366-395. [CrossRef]

4. Loe, T.; Ferrell, L.; Masfield, P. A Review of Empirical Studies Assessing Ethical Decision Makings in Business. J. Bus. Ethics 2000, 25, 185-204. [CrossRef]

5. Healy, P.; Palepu, K. The Fall of Enron. J. Econ. Perspect. 2003, 17, 3-26. [CrossRef]

6. Moon, H. The Relationship between Ethical Management and Discretionary accruals. Korean Account. J. 2007, 16, 81-105.

7. Pae, J.; Choi, T. Business Ethics and Financial Reporting Quality: Evidence from Korea. J. Bus. Ethics 2011, 103, 403-427.

8. Stevens, B. Corporate Ethical Code: Effective Instruments for Influencing Behavior. J. Bus. Ethics 2008, 78, 601-609. [CrossRef]

9. Norreen, E. The Economics of Ethics: A New Perspective on Agency Theory. Account. Organ. Soc. 1988, 13, 359-369. [CrossRef]

10. Schwepker, C., Jr.; Ingram, T. Improving Sales Performance through Ethics: The Relationship between Salesperson Moral Judgment and Job Performance. J. Bus. Ethics 1996, 15, 1151-1160. [CrossRef]

11. Wimbush, J. Ethical Climate and Ethical Behavior. Ph.D. Thesis, Virginia Polytechnic Institute and State University, Blacksburg, VA, USA, 1991.

12. Wimbush, J.; Sherpard, J. Toward Understanding of Ethical Climate: Its Relationship to Ethical Behavior and Supervisory Influence. J. Bus. Ethics 1994, 13, 637-647. [CrossRef]

13. Cummings, L. The Financial Performance of Ethical Investment Trusts: An Australian Perspective. J. Bus. Ethics 2000, 25, 79-92. [CrossRef]

14. Waddock, S.; Graves, S. The Corporate Social Performance-Financial Performance Link. Strateg. Manag. J. 1997, 18, 303-319. [CrossRef]

15. Westphal, J. Collaboration in the Boardroom: Behavior and Performance Consequences of CEO-board Social Ties. Acad. Manag. J. 1999, 42, 7-24.

16. Epsten, M.; McEwen, R.; Spindle, R. Shareholder Performance Concerning Corporation Ethical Performance. J. Bus. Ethics 1994, 13, 447-453. [CrossRef]

17. Dawkins, J.; Lewis, S. CSR in Stakeholder Expectations: And Their Implication for Company Strategy. J. Bus. Ethics 2003, 44, 185-193. [CrossRef]

18. Hong, H.; Kacperczyk, M. The Price of Sin: The Effects of Social Norms on Market. J. Financ. Econ. 2009, 93, 15-36. [CrossRef] 
19. Hwang, L.; Lee, W.; Nam, H.; Park, K. Conditional Conservatism, Listing Status, and Auditor Quality. Korean Account. Rev. 2008, 33, 145-183.

20. Kothari, S.; Lys, T.; Smith, C.; Watts, R. Auditor Liability and Information Disclosure. J. Account. Econ. 1998, 39, 163-197. [CrossRef]

21. Lobo, G.; Zhou, J. Did Conservatism in Financial Reporting Increase after the Sarbanes-Oxley Act? Initial Evidence. Account. Horiz. 2006, 20, 57-73. [CrossRef]

22. Watts, R. Conservatism in Accounting. Part II: Evidence and Research Opportunities. Account. Horiz. 2003, 17, 287-301. [CrossRef]

23. Whang, K. The Study of Managers Income Smoothing Trend. Korean Account. Rev. 1990, 10, 63-88.

24. Ronen, J.; Sadan, S. Smoothing Income Numbers: Objectives, Means, and Implication; Addison-Wesley: Boston, MA, USA, 1981.

25. Guenther, D. Measuring Earnings Management in Response to Corporate Tax Rate Changes: Evidence from the 1986 Tax Reform Act. Account. Rev. 1994, 69, 230-243.

26. Maydew, E. Tax-Induced Earnings Management by Firms with Net Operating Losses. J. Account. Res. 1997, 35, 83-96. [CrossRef]

27. Sholes, M.; Wilson, G.; Wolfson, M. A Firms Responses to Anticipated Reduction in Tax Rates: The Tax Rate Reform Act of 1986. J. Account. Res. 1992, 30, 161-185. [CrossRef]

28. Beatty, A.; Chamberlain, S.; Magliolo, J. Managing Financial Reports of Commercial Banks: The Influence of Taxes, Regulatory Capital and Earnings. J. Account. Res. 1995, 33, 231-261. [CrossRef]

29. Collins, J.; Shackelford, D.; Wahlen, J. Bank Differences in the Coordination of Regulatory Capital, Earnings and Taxes. J. Account. Res. 1995, 33, 263-291. [CrossRef]

30. Guidry, F.; Leone, A.; Rock, S. Earnings-Based Bonus Plans and Earnings Management by Business Unit Managers. J. Account. Econ. 1999, 26, 113-142. [CrossRef]

31. Healy, P. The Impact of Bonus Schemes on the Selection of Accounting Principles. J. Account. Econ. 1985, 7, 85-107. [CrossRef]

32. Watts, R.; Zimmerman, J. Positive Accounting Theory; Prentice-Hall: Englewood Cliffs, NJ, USA, 1986.

33. Song, I.; Choi, K. Accounting Changes for Income Smoothing and Its Impact on Stock Prices. Korean Account. Rev. 1992, 14, 221-246.

34. Francis, J.; LaFond, R.; Shipper, K. Cost of Equity and Earnings Attributes. Account. Rev. 2004, 79, 967-1010. [CrossRef]

35. Bhattacharya, U.; Daouk, H.; Welker, M. The World Price of Earnings Opacity. Account. Rev. 2003, 78, 641-678. [CrossRef]

36. Li, S.; Richie, N. Income Smoothing and the Cost of Debt; Working paper; Wilfrid Laurier University: Waterloo, Canada, 2009.

37. Ahmed, A.; Billings, B.; Morton, R.; Harris, M. The Role of Accounting Conservatism in Mitigating Bondholder-shareholder Conflicts over Dividend Policy and in Reducing Debt Costs. Account. Rev. 2002, 77, 867-890. [CrossRef]

38. Zhang, J. The Contracting Benefits of Accounting Conservatism to Lenders and Borrowers. J. Account. Econ. 2008, 45, 27-54. [CrossRef]

39. Park, J.; Nam, H.; Choi, S. The Effect of Income Smoothing, Accounting Conservatism, and Discretionary Accruals on Credit Ratings. Korean Manag. Rev. 2011, 40, 1015-1053.

40. Yang, D.; Park, Y.; Choi, S.; Kwon, S. Does Income Smoothing Reduce the Cost of Capital? Korean Account. J. 2007, 16, 57-77.

41. Jung, S.; Yoo, S. The Effect of Voluntary Disclosure and Conservatism on the Cost of Equity. Korean Account. Rev. 2012, 37, 267-308.

42. Jianu, I.; Jianu, I.; Ileanu, B.; Nedelcu, M.; Herteliu, C. The Value Relevance of Financial Reporting in Romania. Econ. Comput. Econ. Cybern. Stud. Res. 2014, 48, 167-182. [CrossRef]

43. Touche Ross. Available online: www.deloitte.com (accessed on 8 November 2015).

44. Kim, S. The Challenge in terms of Korean Companies Competitiveness. In CEO Information (SERI); Samsung Economic Research Institute: Seoul, Korea, 2002; p. 377.

45. Lee, H.; Choi, K. The Ethical Acceptability of Corporate Earnings Management. Korean Account. Rev. 1996, 21, 21-45. 
46. Basu, S. The Conservatism Principle and the Asymmetric timeliness of Earnings. J. Account. Econ. 1997, 24, 3-37. [CrossRef]

47. Khan, M.; Watts, R. Estimation and Empirical Properties of a Firm-Year Measure of Accounting Conservatism. J. Account. Econ. 2009, 48, 132-150. [CrossRef]

48. Kothari, S.; Leone, A.; Wasley, C. Performance Matched Discretionary Accrual Measures. J. Account. Econ. 2005, 39, 167-193. [CrossRef]

49. Dechow, P.; Sloan, R.; Sweeney, A. Detecting Earnings Management. Account. Rev. 1995, 70, 193-225.

50. Francis, J.; LaFond, R.; Shipper, K. The Market Pricing of Accruals Quality. J. Account. Econ. 2005, 39, $259-327$. [CrossRef]

51. McNichols, M. Discussion of the Quality of Accruals and Earnings: The Role of Accrual Estimation Errors. Account. Rev. 2002, 77, 61-69. [CrossRef]

52. Dechow, P.; Dichev, I.D. The Quality of Accruals and Earnings: The Role of Accruals Estimation Errors. Account. Rev. 2002, 77, 35-59. [CrossRef]

53. DeFond, M.; Jiambalvo, J. Debt Covent Violation and Manipulation of Accruals. J. Account. Econ. 1994, 17, 145-176. [CrossRef]

54. Subramanyam, K. The Pricing of Discretionary Accruals. J. Account. Econ. 1996, 22, 249-281. [CrossRef]

55. Harris, T.; Huh, E.; Fairfield, P. Gauging Profitability on the Road to Valuation. In Strategy Report, Global Valuation and Accounting; Morgan Stanley Dean Witter: New York, NY, USA, 2000.

56. Penman, S. Financial Statement Analysis and Security Valuation; McGrawHill/Irwin: New York, NY, USA, 2001.

57. Hageman, R.; Zmijeski, M. Some Economic Determinants of Accounting Policy Choice. J. Account. Econ. 1979, 1, 141-161. [CrossRef]

58. Yoon, S. A Comparison of Earnings Management Between KSE Firms and KOSDAQ Firms. Korean J. Financ. Stud. 2001, 29, 57-85. [CrossRef]

59. Kim, T.; Chun, H.; Kwon, Y. Market Anomaly Audit Quality, Conservatism and Accounting Accruals. Korea Int. Account. Rev. 2011, 36, 115-142.

60. LaFond, R.; Watts, R. The Information Role of Conservatism. Account. Rev. 2008, 83, 447-478. [CrossRef]

61. Jianu, I.; Jianu, I. The Share Price and Investment: Current Footprints for Future Oil and Gas Industry Performance. Energies 2018, 11, 448. [CrossRef]

(C) 2019 by the authors. Licensee MDPI, Basel, Switzerland. This article is an open access article distributed under the terms and conditions of the Creative Commons Attribution (CC BY) license (http://creativecommons.org/licenses/by/4.0/). 